UDC 004.738.5:796.332(474.5)

DOI: https://doi.org/10.30839/2072-7941.2019.177721

\title{
LITHUANIAN FOOTBALL A LEAGUE TEAMS \\ COMMUNICATION ASPECTS ON SOCIAL NETWORK FACEBOOK: EVALUATION OF FOLLOWERS ATTITUDE
}

\author{
C PAKSTYS, ERIKAS \\ Lietuvos Sporto Universitetas (Kaunas, Lithuania) \\ E-mail: erikas.pakstys@gmail.com, ORCID iD : 0000-0002-4877-3511
}

\begin{abstract}
Lithuanian football league have the lowest ranking in all Europe. By this it was choosen to analyze what strategies Lithuanian major teams are using on social network Facebook. Digital technologies based on software and social networks become more effective and integrated, causing transformation in all spheres of the global economy. As European major football clubs shown that more people are interested in football club, the more football club can make a profit. Technology growth driven by that social networks become the main tool to attract more fans to club community. This has opened new science strategy how to use social network to make club growth. The purpose of this study is to analyze what strategies Lithuanian A-league teams are using on Facebook to attract more fans to their community. The objective of the study is to assess the devotees approach to Lithuanian Football Leagueplayed football teams at the social network aspects of cooperation on Facebook. Study methodology. Study methodology includes analysis of the content of the online social networking sites of Lithuanian football teams and survey of 39 questions in order to find out the attitudes of followers to the aspects of cooperation between football teams in the Lithuanian football league in Facebook on Facebook. The scientific novelty of the study. The growth in popularity of football in Lithuania and all over the world to scan all new way to attract more fans to a certain football team. Results of the study. Results show that football teams that want to capture most of their followers must use text or video-type content in communication on social media Facebook. Conclusion. It is very important to fill the content on their social network Facebook, because the needs of the followers are satisfied by the fast and efficient presentation of sports news. In addition, it turned out that the most followers choose to watch the content of their favorite football team's photo or video-type content rather than textual content.
\end{abstract}

Keywords: social media, football, league, follower.

Analysis of the references. Nowadays on the internet you can find many types of social networks. Every social network site are some way different from other but they do similar functions. From now on I will concentrate on 3 main social network sites, becouse they are the most popular in Europe (1 table) (Search Engine Journal, 2016).

Facebook. The social network with the most acitve users is Facebook. Facebook was found in
2004 by Mark Zuckerberg and his collage roomates in the United States of America. The main features of Facebook were finding old and new friends, sharing your thoughts with your friends or any kind of community, you can follow your favorite sports team, music stars etc. These features helped Facebook to gain 1,5 billion active users everyday. Facebook was that network which developed social media to this point as it is today [3, p. 218] . Facts about 
Facebook (Search Engine Journal, 2016): $47 \%$ of all internet users have or using Facebook; 4,5 billion times "like" button is clicked everyday; have more videos than Youtube; 4 billion views everyday.

Twitter. Social network Twitter is the simplest social network. On this network you can share your thoughts along with some video or images. This kind of sharing they call it tweet. In one tweet you only have 140 characters. On this social network you also can get in touch with your favourite person or organization. Twitter is tremendous size, it gather over 100 million active users everyday. Facts about Twitter (table 3) (Search Engine Journal, 2016): over the 2016, the number of Twitter users has grown by more than 50 million; more than $37 \%$ of Twitter users buy a product or service from their tracking brands; 53 million users who use Twitter are from the United States.
Instagram. The social network Instagram is unique in that it can share photos and adjust them in the application to make them look more beautiful. So this network became so popular between youth. Most users are between 18-35 years old. In this social network users can only share information with video or image. This was Instagram's exclusive feature. This network was popular mostly on smarthphones, statistics show that 98\% Instagram users using mobile version. This is the best result compared to other social networks. Facebook so admired Instagram that Facebook bought it in 2012 to avoid big competition. From that day Instagram is connected with Facebook so if you want to share post on Instagram you can share the same post on Facebook. Facts about Instagram (table 4) (Search Engine Journal, 2016): 75 million active users everyday; $90 \%$ users are under 35 years old; $70 \%$ users ar not from Uinted States of America.

Table 1. Statistics of social networks Facebook; Twitter; Instagram (Search Engine Journal, 2016)

\begin{tabular}{|l|c|c|c|}
\hline & Facebook & Twitter & Instagram \\
\hline Active users & 1,55 billion & 316 billion & 400 billion \\
\hline Average time spend in one day & 42 minutes & 17 minutes & 21 minutes \\
\hline Mobile version users & $68 \%$ & $86 \%$ & $98 \%$ \\
\hline Stacionary computer/laptop users & $32 \%$ & $14 \%$ & $2 \%$ \\
\hline Users over 18 years old & $82 \%$ & $32 \%$ & $55 \%$ \\
\hline
\end{tabular}

To understand how individual users, communities, and organizations can use different social media platforms to connect, monitor and engage with each other, [7, p. 243], advanced a honeycomb framework. This honeycomb framework unpacks social media functionalities into seven building blocks (see Fig. 1) [5, p. 432].

Lithuanian football a league teams communication aspects on social network Facebook: evaluation of followers attitude 


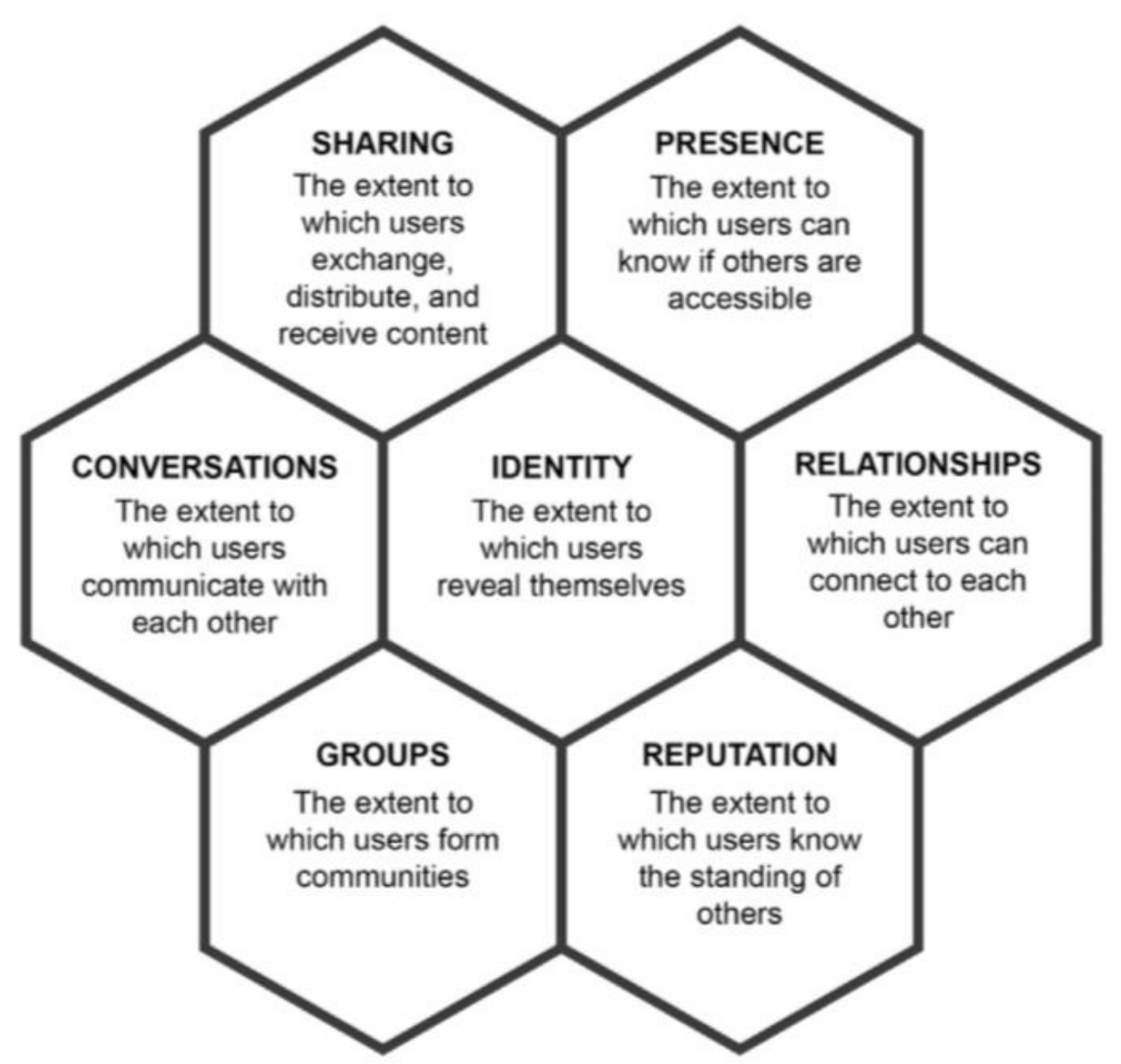

Fig 1. 7 Main functions of social networks (Baccarella et al., 2018)

It is also important to describe the overview of the importance, benefits, bad qualities and features of these seven key social networking features.

Sharing. This feature allows social network users to share certain information with others. For example, users of social network Flickr share photos, Youtube videos, Instagram photos and videos, Twitter - their thoughts (textual expression), and Facebook is a universal social network because it can share everything - videos, photos and thoughts (text). The information shared by the user is called Usergenerated content (UGC) [2, p. 2]. Most popular social networks have discovered what the sharing system should be among consumers [7, p.
245]. Sharing has become so simple and easy that most people forget what copyright is. For example, in the United States in 2007, Stephanie Lenz uploaded a 29 -second video of how her child danced alongside the Prince's song "Let's Go Crazy", created by Prince. The Universal Music Group, which at that time was responsible for artist Prince's copyright, decided that the video should be removed from the Youtube platform and that the author of the video should get fine of US $\$ 150,000$ [5, p. 433] . In summary, sharing can be beneficial, addictive, but if it's irresponsible it become dangerous.

Presence. This feature allows organizations or users to report when they are available to text back, where 
they are in real life, in real time. For example, Facebook, Trapster, Google Maps, and other social networks use Internet Protocol address information (IP). This allows you to determine the location of your phone in real time. Users often use the Check-in feature themselves. This allows users to mark in which places they are, or was, and this can be seen by all other users. Users can be tracked without their consent or warning. As in 2011, Facebook launched the Messenger app. The settings provided by this application manufacturer enabled us to track the content of the messages and their geographical location. In 2012, as a result of this function, organizations reported violation of their privacy, but did not receive the results of the belief organizations, no changes were made [5, p. 434].

Conversations. The system of intercommunication allowed users to communicate, discuss and express their opinions on social networks without restriction. This feature has opened up new opportunities to communicate freely and has created a strong competitor for mobile phone networks operators. Social networks like Twitter, Facebook, Instagram, LinkedIn have "Like", "Reply", "Comment", "Write Message" features. They allow users to communicate with each other in a variety of ways. The dark side of this function is bullying, threats and uncontrollable communication. Also, this feature enabled Chatbot to appear. These robots were so sophisticated that they deceived the editor of two American scientific journals and forced him to believe he was a loved one with whom he interacted. Later it turned out that it was a chat robot [5, p. 433].

Identity. Every user creates his / her identity on the social network. Every click on the "Like" feature, joining a user-friendly group, writing a comment is captured, and each other user can see what the person is when viewing his profile [4, p. 434]. Such self-propagation in unlimited space can have very bad consequences. A recent UK survey showed that most children and adolescents do not have security on social networks. Most use this feature as a means of persecution, but checking social networking profiles, such as those of a former spouse, is not considered to be relatively dangerous $[13$, p. 711$] ;[5$, p. 434]

Realationships. It is a feature that allows social networks to converge with other users. For example, the social network LinkedIn is a relationship based on work. Other users can see who they worked with, who they work with, who they work with, and so on. For comparison, Facebook describes relationships as a relationship of friendship. Facebook users can use the Friends of Friends function and find out who the user is communicating with or on their friends list. The relationship function, like the others mentioned above, has minuses. This is repeated with the abovementioned qualities: bullying, persecution and insulting in the online space [11, p. 17][5, p. 434].

Groups. Every user on a social network can belong to a particular group and can create their own group. There are two types of groups on the

Lithuanian football a league teams communication aspects on social network Facebook: evaluation of followers attitude 
Facebook platform: open and closed groups. Users in these groups communicate with each other, present themselves, or share certain information with other users. The negative qualities of groups, as the psychiatrists call it, are the group's internal-group external bias (ingroupoutgroup bias). This means that some users are in good agreement with other members of the group because they share common interests and agree. But with the other members of the group, there is a rejection without a warm relationship. This is called "group love" and "outgroup hate" [5, p. 434].

Reputation. Reputation on social networks is measured by the number of followers, the number of comments, post user records, or the number of views after a particular uploaded video. This allows the user to understand how popular the user is being tracked and can compare with other users and decide which is more interesting. Like Zrakova, Ferenc and Adamik (2017), the reputation not only represents a positive image of the organization, but it helps the organization to stand up against the audience as a prestigious company, creating positive links to itself and helping to develop the organization's sports brand. To get a good reputation you need to know what audience your organization is interacting with, you need to know what the audience requires and how to motivate the audience $[24, \quad$ p. 20]. Main reputational risk, improper upload of content. This can very quickly ruin the long-standing reputation. Most business magicians, politicians, or other social networking users, after an inappropriate, offensive, published post, must resign from the job. In order to protect the reputation of their company, employers analyze their social networking profile before accepting a new person and see if there are published offensive records [19, p. 83]. In 2010, 44\% of employers searched for information about employees on social networks before they accept to work, where needed professional skills [14, p. 3][4, p. 434]. Also, reputation is defined as a combination of attitude, expectation, and audience criticism that are very important to a sports organization. Keeping in touch with members of your football community is crucial to your sporting organization's positive reputation. It is also very important to keep in touch with the media, because it is the image of the sports organization that is made for public [24, p. 20].

The number of social network users has grown very strongly over the past decade. With social networking, one person can now communicate with hundreds or even thousands of their customers. As social networks are free, there is a chance to connect people who are interested in a common topic [8, p. 728]. Effective use of social networks and direct communication with your audience is acceptable to all sports organizations. Managers who work well should be aware of the need to develop information and communication using modern technologies [20, p. 73]. According to Pew Research (2014), 74\% of adults on the Internet use social networks. According to Lewis, the Internet user is no longer a passive media viewer. 
Nowadays the users has the opportunity to create and share interactive media himself. By this communication became much easier $[25$, p. 729$]$.

Over the last decade, the number of social networks has increased dramatically. Football clubs can now choose from a wide range of two hundred popular social networks [25, p. 729]. As Lewis and Kitchin (2011) have said, "The social network for sports organizations has lifted all the barriers between sports organizations and consumers, creating a more tangible and energetic relationship."[11, p. 192]. It is no longer so important for sports organizations to interact with journalists as they did before, and now they can reach their consumers through social media. Sports organizations can't ignore the benefits of social networks. Social networks offer to connect sports organizations with their clients and help build longterm relationships [25, p. 728].

The importance of social networks to see a sports organization is not difficult. Social media has drastically changed the interaction between the organization and its users, otherwise called fans. Abosag, Roper, and Hind (2012) Referring to sports marketing literature, fans have a special relationship with their favorite teams[1, p. 1233]. Fan communities and the positive qualities of the organization itself [22, p. 37]. The concept of sport takes part in all processes, demonstrating the highest achievements of a person in the development of physical, mental, personal qualities. [4 p. 12]. The sports organization benefits from social networking as a supportive community for its attachment to itself. consumers have a strong positive attitude and a more intense approach to the product and service provided by a sports organization [18,p . 4]. This shows how important it is to develop loyal followers of a sports organization. Communicating with your supporters will be easier every year, as Internet access by Kendley (2015) will reach $71 \%$ in 2019 worldwide. This means that through social networks, sports organizations increase the ability to reach their users anywhere.

Social networks have opened up new opportunities to reach more of their customers, which could not be reached through traditional advertising channels. One of the key benefits of a positive social network is social networking tools such as Youtube, Twitter or Facebook, which are attracting an increasing audience. These tools help to create more attractive content [25, p. 728]. The second-generation web has created an opportunity to exchange any information on the Internet. With the opportunity to share photos, videos or textual information, the communication between sports organizations and their fans has changed dramatically [8, p. 79]. According to Facebook, users spend 700 billion minutes each month using the social network[16, p. 167]. This shows that social network Facebook users spend most of their free time on the social network.

Communication in sport is a dynamic practice that includes many

Lithuanian football a league teams communication aspects on social network Facebook: evaluation of followers attitude 
of the functions of the sports industry from brand, reputation, management, customer service, marketing and sponsorship [17, p. 2]. This shows the importance of communication in sport. Communication in social networks has become a higher quality and wider spectrum for sports organizations. Social networks have changed the principle of mutual communication. Sports organizations can not only communicate with their audience, but also the audience can communicate with each other $[10, \mathrm{p}$. 307].

Recently, sports managers have been challenged to use social networks to improve communication with their fans. With the right use of networks, sports organizations create long-lasting relationships with their audience on the social network. In order to choose the right tools to improve the relationship with the fans, it is very important to analyze and find the factors that motivate the fans to participate in their community [6, p. 34]. Roserberger (2015) conducted a survey in Brazil to identify factors that influence the motivation of fans. 483 participants participated in the survey. 337 of them were football fans and 146 were poeple who not interested in football. Following the study, Roserberger identified six motivations that encourage Brazilian fans to participate in football - team interest, socialization, aesthetics, sports baggage, sports interest, and team achievements. The following factors were suitable for football fans: team interest, socialization, team achievements, sports interest and aesthetics.
Participation

of sports organizations in social networks such as Facebook is very important. In this network, the organization allows users to familiarize themselves with the sports logo and at the same time share their daily activities with their community [20, p. 80]. So sport has been named as an excellent example of having a common interest in creating online communities, giving the opportunity to interest existing and future communities of fans [22, $\mathrm{p}$. 39]). Previous research has shown various strategies for sports organizations to develop content that improves relationships with their fans. Including Positivity, Disclosure, Legality Guarantees, Tolerance, Leadership, Rapid Response, Education Communication and Respect Strategies [9, p. 3].

Buying tickets to sporting events online is no longer a novelty. Earlier research shows that 8,000 fans who bought tickets online (via Ticketmaster) found that social media platforms such as Twitter or Facebook are three times more effective in terms of sales than other traditional marketing methods $[15$, p. 32].

Summarizing the impact of the social network on a sports organization, it can be said that social networks open up new opportunities for sports organizations to communicate, create and share information with their fans and followers.

Research Methodology. The aim of the research was to evaluate the attitude of followers to the aspects of communication of football teams playing in Lithuanian football A league on Facebook. Leonor Vale and 
Teresa Fernandes (2017) questionnaires were chosen to achieve the main goal of the study. The study was conducted using a quantitative survey method - a closed-ended questionnaire, where respondents had to choose the correct answer. The questionnaire consisted of 39 questions.

Questions were divided into 7 groups (Figure 2).

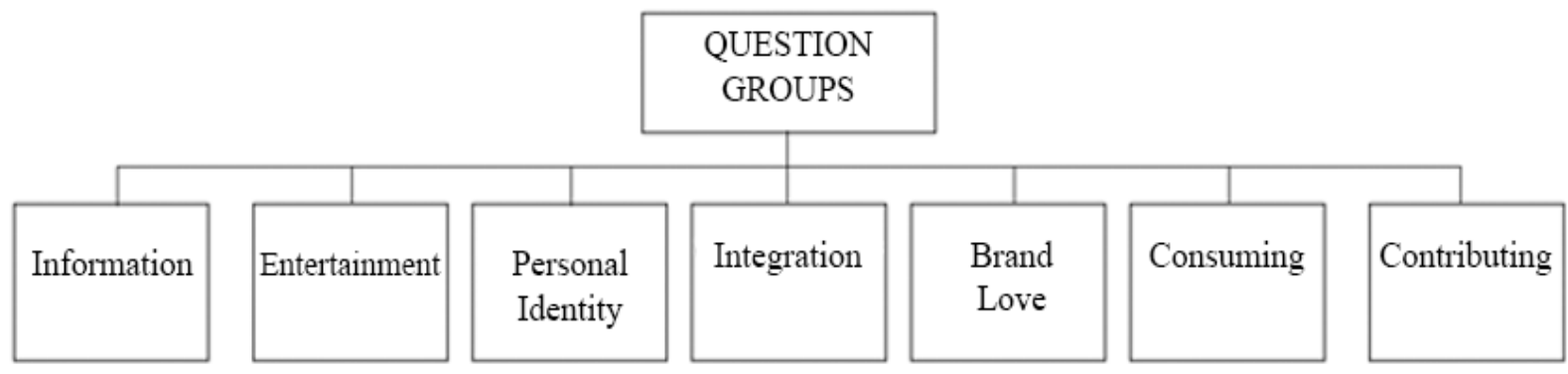

Fig. 2 Question groups (Vale et al., 2017)

The questionnaire used the 7 answers Likert scale (from 1 - totally disagree to 7 - totally agree). About 1000 questionnaires were sent out during the survey. The 354 followers participated in the survey. Data analysis was done using SPSS 25.0 version.

An analysis of the content of the online social networking sites of Lithuanian football team on Facebook was analysed using Kim \&
Kuljis(2010) methodology. Currently, the highest league in Lithuania is League A, consisting of 8 teams Vilnius Zalgiris, Kaunas Žalgiris, Trakai, Marijampolè Sūduva, Klaipeda Atlanta, Palanga, Kaunas Stumbras and Jonava. All listed teams have their own accounts on Facebook and have web pages, and only 3 teams have accounts on the social network Twitter and 3 teams have accounts on the Youtube channel (Table 2).

Table 2. Lithuanian football A league teams with social network accounts

\begin{tabular}{|l|c|c|c|c|}
\hline Team & Facebook & Twitter & Youtube & Webpage \\
\hline Marijampolès Sūduva & + & - & + & + \\
\hline Vilniaus Žalgiris & + & + & + & + \\
\hline Trakai & + & - & - & + \\
\hline Kauno Stumbras & + & + & - & + \\
\hline Kauno Žalgiris & + & + & - & + \\
\hline Klaipeddos Atlantas & + & - & + & + \\
\hline Palanga & + & - & - & + \\
\hline Jonava & + & - & - & + \\
\hline
\end{tabular}

Results and discussion.

A survey of Lithuanian football A league team followers' opinion on filling their favorite team's content on
Facebook revealed that all followers agree that sports news is useful to them. This shows how important it is for football teams to raise information

Lithuanian football a league teams communication aspects on social network Facebook: evaluation of followers attitude 
on their social network Facebook accounts. The followers of all teams agree that they like to participate in the community because they feel right and want to reveal themselves to other members of the community, i.e. participate in its activities. Such results show that football teams need to develop their communities to attract more of their followers. All A league followers agree that the rapid transfer of information is useful and necessary for them. It is a good idea for a football team to quickly submit their main news to the followers, as this will satisfy their needs. Also, football followers agree that they read what their favorite team is about. Such results show that Lithuanian football A league teams are creating content that is interesting for their followers. The results show that all A league followers similarly agree to hit the "Like" button on the team uploaded content. Like Baccarella et al. (2018) states that by sharing the information, building, communicating, identity, building relationships, and community development among sports organizations, the organization improves relationships with its fans and develops its own sports brand.

Survey results showed that it is important for football teams to fill their content on Facebook. Followers' needs are met by the fast and efficient delivery of sports news. If football teams meet the needs of followers, they want to spend more time with their favorite team and their community. Satisfying the needs of the followers, they share positive information with other people about the team's activities, thus increasing the number of followers and improving the team's reputation.

Comparing the responses of individual Lithuanian football A league team followers, it can be concluded that all followers have a similar opinion about the football team's content on Facebook. This shows that all teams need to use similar tools to attract more of their followers to their community.

After analyzing the survey results, one can assume that most followers like text information. This statement has the most positive results $(90.1 \%)$, while the interest in video-type content is lower $-82.5 \%$, while the content of photo-type content has the lowest acceptance - 79.9\%. It can be said that the followers of the Lithuanian Football A league team like the text-type content, and the second most popular is the content of the videos. Football teams that want to capture most of their followers must use text or video-type content.

The results of the survey show that the highest average was received for the statement The sport-related information is useful (6.06) and the lowest for the statement I like participating in this community because it is entertaining (5.63). In general, the means of all statements are very close to each other: I want to express what kind of person I am (5.65); I want to get a better service (5.64); I read the content posted by the sport club on Facebook (5.76); I 'like' content posted by the sport club on Facebook (5.66).

According to the survey it can be stated that due to the low popularity of football as a sport in Lithuania, the teams such as Jonava, Palanga or 
Kaunas Stumbras were inactive in the survey.

\section{Conclusion.}

Disclosing the theoretical aspect of social networks, it can be said that social networks for sports organizations are of great importance in creating football follower communities. Social networks have made it easier for sports organizations to communicate with their followers. Using social networking features such as sharing, presence, communication, identity, relationship building, community, and reputation building for sports organizations can create content that meets the needs of followers.

Following the analysis of the scientific literature, it can be said that Facebook is the most popular social network at the moment, and the number of users in this network exceeds all other social networks. With the help of this social network, communication between sports organizations and their followers has become much more effective than traditional ways of communication between sports organizations.

After completing the survey it turned out that it is important for the teams playing in Lithuanian football league to fill the content on their social network Facebook, because the needs of the followers are satisfied by the fast and efficient presentation of sports news. In addition, it turned out that the most followers choose to watch the content of their favorite football team's photo or video-type content rather than textual content.

\section{REFERENCES}

1. Abosag, I., Roper, S. and Hind, D. (2012). Examining the relationship between brand emotion brand extension among supporters of professional football clubs. European Journal of Marketing, 46. DOI:10.1108/03090561211247810.

2.Berthon, P., Pitt, L., Kietzmann, J. and McCarthy, I. P. (2015). CGIP: Managing consumer-generated intellectual property. California Management Review, 57(4), 43-62.

3. Boyd, D. and Elisson, N. (2008). Social network sites: definition, history and scholarship. Journal of computer-mediated communication, 13.

4. Bilohur, V. (2018). Conceptial sport formation as a sociasystem, social institute and social movement in conditions of globalization. Humanitarian Bulletin of Zaporizhzhia State Engineering Academy, 73, 13-24.

5. Christian, V. Baccarella, Tim, F. Wagner, Jan H., Kietzmann and Ian, P. McCarthy. (2018). Social media? It's serious! Understanding the dark sida of social media. European Managment Journal, 36, 431- 438.

6. Kuklyte, J. and Murauskas, V. (2017). Sports fans motivation: interaction is social networks. Mokslas ir praktika. Aktualijos ir perspektyvos, 33-34.

7. Kietzmann, J. H., Hermkens, K., McCarthy, I. P. and Silvestre, B. S. (2011). Social media? Get serious! Understanding the functional building blocks of social media. Business Horizons, 54(3), 241-251.

8. Kim, I. and Kuljis, J. (2010). Applying content analysis to Web-based content. Journal of computing and information technology. CIT 18. 369-375p. doi:10.2498/cit.1001924

9. Kim, D. H., Kwon, E. S., Song, Y. and Sung, Y. (2015). Connecting to the elusive sports fan: Sports fan relationship managment in Facebook. The journal of advertising and promotion research. Vol 4. No. 1. 77-108 p. DOI: 10.14377/JAPR.2015.3.31.77.

10. Kuvykaite, R. and Piligrimiene, Z. (2013). Communication in social media for company's image formation. Economics and management, 18 (2).

Lithuanian football a league teams communication aspects on social network Facebook: evaluation of followers attitude 
11. Kwan, G. C. E. and Skoric, M. M. (2013). Facebook bullying: An extension of battles in school. Computers in Human Behavior, 29(1), 16-25.

12. Lewis, R. ir Kitchin, P. (2011). New Communications for sport, in M. Hopwood, P. Kitchin and Skinner (Eds). Sport Public Relations and Communication, 187-214.

13. Lyndon, A., Bonds-Raacke, J. and Cratty, A. D. (2011). College students' Facebook stalking of ex-partners. Cyberpsychology, Behavior, and Social Networking, 14(12), 711-716.

14. Madden, M. and Smith, A. (2010). Reputation Management and Social Media - how people monitor their identity and search for others online. Washington, D.C.

15. Moyer, C. Pokrywczynski and Griffin, R. J. (2015). The Relationship of fans sportsteam identification and Facebook usage to purchase of team products. Journal of sports media, vol. 10, number 1. 31-49 p.

DOI: $10.1353 /$ jsm.2015.0001.

16.Özsoy, S. (2011). Use of new media by Turkish fans in sport communication: Facebook and Twitter. Journal of nationally acknowledged by C.N.C.S.I.S, XI, 2.

17. Prabhu, S. (2011) Social media in sports communication marketing essay. Batch Rol, 203.

18. Rosenberger, P.J., Yun, J. H., Raham, M. M., De Oliveira and M.J. Kocher, S. (2015). Investigating motivation drivers of attitudinal and behavioural fan loyalty in Brazil: football verus other sports. Konferencija: 50 Asamblea Anual de Cladea 2015 - Consejo Latinoamericano de Escuelas de Administración, 1-13.

19. Roulin, N. (2014). The influence of employers' use of social networking websites in selection, online self-promotion, and personality on the likelihood of faux pas postings. International Journal of Selection and Assessment, 22(1), 80-87.

19. Suguencia, L. O., Herman, D., Marzano, G., Rodak, P. (2017). The role of social media in sports communication management: an analysis of Polish Top League team's strategy. Procedia Computer Science, 104.

20. Tsai, W. and Men, L. (2013). Motivations and antecedents of consumer engagement with brand pages on social networking sites. Journal of Interactive Advertising, 13, 76-87. doi:10.1080/15252019.2013.826549 .

21. Valackienè, A. (2004). Sociologinis tyrimas: vadovèlis. Kaunas: Technologija.

22. Vale, L.and Fernandes, T. (2017). Social media and sports: driving fan engagment with football clubs on Facebook. Journal of strategic marketing vol. 26. 37-55.

23. Van, Dijck, J. (2009). Users like you? Theorizing agency in user-generated content. Media, Culture \& Society, 31(1), 41-58.

24. Zrakova, D., Ferenc, P. and Adamik, R. (2017). Online reputation in sports organization. 8th Comparative European Research. 20-23.

25. Kuzma, J. and Bell, V. (2014) A Study of the Use of Social Media Marketing in the Football Industry. Journal of Emerging Trends in Computing and Information Sciences. 728738.

ПАКШТІ, ЕРІКАС - студент Департаменту спортивного менеджменту, Литовський університет спорту (Каунас, Литва)

E-mail: erikas.pakstys@gmail.com, ORCID iD : 0000-0002-4877-3511

\section{ЛИТОВСЬКА ФУТБОЛЬНА ЛІГА У КОМУНІКАЦІЙНИХ ВИМІРАХ СОЦІАЛЬНОЇ МЕРЕЖІ ҒАСЕВООК: ЕВОЛЮЦІЯ ФУТБОЛЬНИХ ПЕРЕВАГ}

Загальні положення. Литловська футбольна ліга має самий низький рейтинг у всій Європі.Тому я вирішив проаналізувати, які стратегії використовують великі стратегії використовують литовські великі клуби у соціальній мережі Facebook. Цифрові технології, що базуються на програмному забезпеченні і соціальних мережах, стають все більш ефективними та інтегрованими, викликаючи перетворення у всіх сферах 
світової економіки. Як показало дослідження, чим більше людей цікавляться футбольним клубом, тим більший прибуток може отримати футбольний клуб. Отримані кошти вони можуть інвестувати у гравців, розвиток клубної інфрастурутури тощо. Зростання технологій зумовлене тим, що соціальні мережі виступають основним інструментом залучення великої кількості прихильників у клубне товариство, відкриває нову наукову стратегію використання соціальної мережі для зростання популярності клубу. Мета даного дослідження - проаналізувати, які стратегії використовують литовські клуби A-league у Facebook, щоб залучити більше прихильників у своє товариство, а також оцінити відношення вболівальників до футбольних клубів литовської футобольної ліги у соціальній мережі Facebook.

Методологія дослідження. Методологія дослідження включає у себе аналіз змісту онлайнових сайтів соціальних мереж литовських футбольних команд і відповіді на 39 питань 3 метою визначення відношення підписників до аспектів співпраці між футбольними командами у литовській футбольній лізі у Facebook.

Наукова новизна дослідження. Зростання популярності футболу у Литві і в усьому світі дозволяє сканувати все нові способи залучення більшої кількості вболівальників до певного футбольного клубу. Згідно з результатами дослідження очевидно, що футбольні команди, які хочуть залучити найбільшу кількість прихильників, повинні використовувати текстовий чи відео-контент.

Висновок. Надзвийчайно важливо наповнити контент своєї соціальної мережі Facebook, адже потреби підписників задовольняються швидкою i ефективною презентацією спортивних новин. Крім того, більшість підписників намагаються використати фото чи відео контент своєї улюбленої футбольної команди, а не текстовий його варінт.

Ключові слова: соціальні медіа, футбол, ліга

ПАКШТИС, ЭРИКАС - студент Департамента спортивного менеджмента, Литовский университет спорта (Каунас, Литва)

E-mail: erikas.pakstys @gmail.com, ORCID iD : 0000-0002-4877-3511

\section{ЛИТОВСКАЯ ФУТБОЛЬНАЯ ЛИГА В КОММУНИКАЦИОННЫХ ИЗМЕРЕНИЯХ СОЦИАЛЬНОРЙ СЕТИ ҒАСЕВООК: ЭВОЛЮЦИЯ ФУТБОЛЬНЫХ ПРЕДПОЧТЕНИЙ}

Общие положения. Литовская футбольная лига имеет самый низкий рейтинг во всей Европе. Поэтому я решил проанализировать, какие стратегии используют литовские крупные клубы в социальной сети Facebook. Цифровые технологии, основанные на программном обеспечении и социальных сетях, становятся все более эффективными и интегрированными, вызывая преобразования во всех сферах мировой экономики. Как показали исследования, чем больше людей интересуется футбольным клубом, тем больше футбольный клуб может получить прибыль. Полученные деньги они могут инвестировать в игроков, развитие клубной инфраструктуры и т. д. Рост технологий, обусловленный тем, что социальные сети становятся основным инструментом привлечения большего количества поклонников в клубное сообщество, открывает новую научную стратегии использования социальной сети для роста популярности клуба. Цель данного исследования-проанализировать, какие стратегии используют литовские клубы A-league на Facebook, чтобы привлечь больше поклонников в свое сообщество, а также оценить отношение болельщиков к футбольным клубам литовской футбольной лиги в социальной сети Facebook.

Методология исследования. Методология исследования включает в себя анализ содержания онлайновых сайтов социальных сетей литовских футбольных команд и

Lithuanian football a league teams communication aspects on social network Facebook: evaluation of followers attitude 
ответы на 39 вопросов с целью выяснения отношения подписчиков к аспектам сотрудничества между футбольными командами в литовской футбольной лиге в Facebook.

Научная новизна исследования. Рост популярности футбола в Литве и во всем мире позволяет сканировать все новые способы привлечения большего количества болельщиков к определенному футбольному клубу. По результатам исследования видно, что футбольные команды, которые хотят привлечь наибольшее количество поклонников, должны использовать текстовый или видео-контент. Вывод. Очень важно наполнить контент своей социальной сети Facebook, ведь потребности подписчиков удовлетворяются быстрой и эффективной презентацией спортивных новостей. Кроме того оказалось, что большинство подписчиков предпочитают использовать фото или видео контент своей любимой футбольной команды, а не текстовый его вариант.

Ключевые слова: социальные медиа, футбол, лига

Стаття рекомендована до публікації д.філос.н., проф.М.А.Лепським (Запоріжжя, Україна) Надійшла до редколегіï: 07.06.2019 р. Прийнята до друку: 17.06.2019 p. 